\title{
Hubungan antara Kadar Leptin Serum dan Manifestasi Penyakit Atopik pada Anak Obes
}

Dita Lasendra, ${ }^{*}$ Harry Raspati, ${ }^{*}$ Budi Setiabudiawan

Departemen Ilmu Kesehatan Anak Fakultas Kedokteran Universitas Padjadjaran/Rumah Sakit Dr. Hasan Sadikin Bandung

Latar belakang. Kadar leptin meningkat pada obesitas sehingga diduga ada peran leptin dalam menimbulkan manifestasi penyakit atopik.

Tujuan. Mengetahui hubungan antara kadar leptin serum dan manifestasi penyakit atopik pada anak obesitas.

Metode. Penelitian cross sectional yang dilaksanakan pada bulan November 2013, melibatkan siswa beberapa Sekolah Dasar di Kota Bandung usia 6-11 tahun, terbagi menjadi kelompok anak obesitas dan gizi normal, masing-masing 34 anak. Dilakukan anamnesis untuk memperoleh data riwayat penyakit atopi di keluarga dan faktor lingkungan yang memengaruhi atopi, pemeriksaan uji tusuk kulit untuk mengetahui adanya atopi, pemeriksaan ELISA untuk kadar leptin serum, dan kuesioner ISAAC untuk manifestasi penyakit atopik. Analisis statistik yang digunakan adalah uji chi kuadrat. Kurva ROC digunakan untuk melihat batas kadar leptin yang dapat menimbulkan manifestasi penyakit atopik.

Hasil. Kadar leptin tinggi lebih banyak didapatkan pada anak obes dengan manifestasi penyakit atopik ( $\mathrm{n}=20)$ dibandingkan dengan tanpa manifestasi penyakit atopik $(\mathrm{n}=10)$ dan anak gizi normal dengan manifestasi penyakit atopik $(\mathrm{n}=10)$ maupun tanpa manifestasi penyakit atopik $(\mathrm{n}=13)(\mathrm{p}=0,04)$.

Keimpulan. Kadar leptin serum tinggi lebih banyak didapatkan pada anak obes dengan manifestasi penyakit atopik dibandingkan dengan anak obesitas tanpa manifestasi penyakit atopik. Sari Pediatri 2015;17(1):35-40.

Kata kunci: obesitas, atopi, manifestasi penyakit atopik, leptin

\section{Relationship between Serum Leptin and Atopic Manifestation in Obese Children}

Dita Lasendra, Harry Raspati, Budi Setiabudiawan

Introduction. It has been shown that serum leptin increases in obesity, we expect that higher than normal serum leptin level might be a causal factor in the manifestation of atopic disease.

Objective. To analyze the relation of serum leptin and atopic manifestation and as a risk factor resulting in atopic manifestation. Methods. The study was a cross sectional study, involving elementary school students in Bandung aged 6-11 years old, in November 2013 with children classified as obese and normal nutrition status, and numbered 34 children in each group. History including ISAAC questionnaire, skin prick test, ELISA assay for leptin were conducted to obtain data. Chi square test was used for statistical analysis.

Results. Atopic manifestation ( $\mathrm{n}=20)$ was more common in obese children with high serum leptin than obese children with normal/ low leptin serum $(n=0)$ and normal nutrition status children with high $(n=10)$ or normal/low serum leptin level $(n=4)$, $p=0.04$. Leptin value which had significant effect in resulting atopic manifestation in obese children was $>22.503 \mathrm{pg} / \mathrm{ml}$.

Conclusion. High leptin serum was significantly more common in obese children with atopic manifestation and was considered as a risk factor in resulting atopic manifestation in obese children. Sari Pediatri 2015;17(1):35-40.

Keywords: obesity, atopy, atopic manifestation, leptin

Alamat korespondensi: Dr. Dita Lasendra. Departemen Ilmu Kesehatan Anak Fakultas Kedokteran Universitas Padjadjaran/Rumah Sakit Dr. Hasan Sadikin. Jl. Pasteur No. 38 Bandung 40163, Indonesia. Telepon+6222-2035957. E-mail:drdita@yahoo.com 
S elama 20 tahun terakhir, prevalensi obesitas meningkat secara signifikan. ${ }^{1,2}$ Menurut data dari national health and nutritional survey (NHNES), terjadi peningkatan prevalensi obesitas pada anak kelompok 6-11 tahun. ${ }^{2}$ Penderita obesitas berisiko mengalami beberapa komplikasi, termasuk di antaranya atopi. Pada obesitas terjadi akumulasi jaringan lemak yang berlebihan. Jaringan lemak yang terdiri dari adiposit, seperti leptin, merupakan sumber mediator inflamasi. Leptin adalah protein yang dikode oleh gen obese $(\mathrm{Ob})$ dan dihasilkan oleh sel adiposit. Kadar leptin 4-6 kali lebih besar pada obesitas. ${ }^{3,4}$ Leptin pada obesitas inilah yang diduga memiliki peranan dalam berkembangnya atopi. ${ }^{5}$

Penelitian yang telah dilakukan sebelumnya menunjukkan adanya peranan leptin dalam menjelaskan hubungan antara obesitas dan penyakit atopi pada anak. Penelitian di Mesir tahun 2009 ditunjukkan kadar serum leptin lebih tinggi pada penderita asma dibandingkan non asma. ${ }^{6}$

Penelitian ini bertujuan untuk mengetahui hubungan antara kadar leptin serum dengan manifestasi penyakit atopik pada anak obesitas.

\section{Metode}

Penelitian dilakukan mulai bulan November 2013 dengan subjek anak usia 6-11 tahun yang berasal dari beberapa Sekolah Dasar (SD) di Kotamadya Bandung yang telah mendapat persetujuan dari orang tua untuk mengikuti penelitian dan sudah menandatangani persetujuan. Subjek penelitian terbagi menjadi anak dengan status gizi obesitas dan normal, masing-masing

Tabel 1. Karakteristik umum subjek penelitian

\begin{tabular}{|c|c|c|c|c|}
\hline \multirow{3}{*}{ Karakteristik } & \multicolumn{4}{|c|}{ Manifestasi penyakit atopik } \\
\hline & \multicolumn{2}{|c|}{ Obesitas $(n=34)$} & \multicolumn{2}{|c|}{ Normal $(n=34)$} \\
\hline & Ada & Tidak ada & Ada & Tidak ada \\
\hline \multicolumn{5}{|l|}{ Jenis kelamin } \\
\hline Laki-laki & 10 & 6 & 9 & 8 \\
\hline Perempuan & 10 & 8 & 5 & 12 \\
\hline \multicolumn{5}{|l|}{ Pendidikan ibu } \\
\hline Dasar & 0 & 2 & 0 & 0 \\
\hline Menengah pertama & 0 & 2 & 0 & 5 \\
\hline Menengah atas & 12 & 7 & 8 & 9 \\
\hline Tinggi & 8 & 3 & 6 & 6 \\
\hline \multicolumn{5}{|l|}{ Pendidikan ayah } \\
\hline Dasar & 0 & 2 & 0 & 1 \\
\hline Menengah pertama & 1 & 1 & 0 & 1 \\
\hline Menengah atas & 14 & 7 & 6 & 12 \\
\hline Tinggi ${ }^{\circ}$ & 5 & 4 & 8 & 6 \\
\hline \multicolumn{5}{|l|}{ Penghasilan } \\
\hline < UMR* & 1 & 2 & 3 & 2 \\
\hline$>$ UMR & 19 & 12 & 11 & 18 \\
\hline \multicolumn{5}{|l|}{ Atopi } \\
\hline Negatif & 4 & 10 & 6 & 15 \\
\hline Positif & 16 & 4 & 8 & 5 \\
\hline
\end{tabular}

*UMR: upah minimun regional 
kelompok terdiri atas 34 anak. Subjek yang sebelumnya mengonsumsi obat-obatan yang mengganggu respon uji tusuk kulit, dermatografisme, dan kelainan dermatologis yang luas dieksklusi. Penelitian dilakukan secara analitik komparatif dengan rancangan cross sectional. Dilakukan anamnesis untuk memperoleh data adanya riwayat penyakit atopi di keluarga dan faktor lingkungan yang memengaruhi atopi. Bukti adanya atopi diperoleh dari pemeriksaan uji tusuk kulit. Pemeriksaan kadar leptin serum menggunakan metode ELISA dan kuesioner ISAAC digunakan untuk mengetahui manifestasi penyakit atopik. Analisis statistik yang digunakan adalah uji chi kuadrat.

\section{Hasil}

Tidak ada perbedaan yang bermakna antara jenis kelamin, pendidikan ayah, pendidikan ibu, dan penghasilan keluarga dalam menimbulkan manifestasi penyakit atopik $(\mathrm{p}<0,05)$. Manifestasi penyakit atopik pada kelompok anak obesitas $(\mathrm{n}=16)$ dan status gizi normal $(\mathrm{n}=8)$ lebih banyak didapatkan atopi positif dibandingkan dengan kelompok obesitas tanpa manifestasi penyakit atopik $(\mathrm{n}=4)$ maupun kelompok gizi normal tanpa manifestasi penyakit atopik $(\mathrm{n}=5)$ (Tabel 1$)$.

Tidak didapatkan perbedaan bermakna antara variabel riwayat keluarga dengan atopi, penggunaan karpet, asap rokok, dan persalinan $(\mathrm{p}>0,05)$ (Tabel 2). Perbedaan kadar leptin serum antara anak dengan manifestasi penyakit atopik dan anak tanpa manifestasi penyakit atopik pada kelompok anak obesitas dan status gizi normal tertera pada Tabel 3 .

Berdasarkan Tabel 3 terlihat kadar leptin tinggi lebih banyak didapatkan pada anak obesitas dengan manifestasi penyakit atopik $(\mathrm{n}=20)$ dibandingkan dengan tanpa manifestasi penyakit atopik $(n=10)$ dan anak gizi normal dengan manifestasi penyakit atopik

Tabel 2. Karakteristik faktor yang memengaruhi atopi

\begin{tabular}{|c|c|c|c|c|c|}
\hline \multirow{3}{*}{ Karakteristik } & \multicolumn{4}{|c|}{ Manifestasi penyakit atopik } & \multirow{3}{*}{ Nilai $\mathrm{p}^{*}$} \\
\hline & \multicolumn{2}{|c|}{ Obesitas $(n=34)$} & \multicolumn{2}{|c|}{ Normal $(n=34)$} & \\
\hline & Ada & Tidak ada & Ada & Tidak ada & \\
\hline Riwayat keluarga dengan atopi & & & & & 0,13 \\
\hline Positif & 5 & 3 & 3 & 0 & \\
\hline Negatif & 15 & 11 & 11 & 20 & \\
\hline Karpet & & & & & 0,22 \\
\hline Ya & 9 & 5 & 4 & 3 & \\
\hline Tidak & 11 & 9 & 10 & 17 & \\
\hline Asap rokok & & & & & 0,47 \\
\hline Ya & 4 & 6 & 3 & 6 & \\
\hline Tidak & 16 & 8 & 11 & 14 & \\
\hline Persalinan & & & & & 0,45 \\
\hline Normal & 17 & 13 & 11 & 19 & \\
\hline Operasi & 3 & 1 & 3 & 1 & \\
\hline
\end{tabular}

Tabel 3. Hubungan kadar leptin serum dengan manifestasi penyakit atopik

\begin{tabular}{|c|c|c|c|c|c|}
\hline \multirow{3}{*}{ Kadar leptin serum } & \multicolumn{4}{|c|}{ Manifestasi penyakit atopik } & \multirow{3}{*}{ Nilai $\mathrm{p}^{*}$} \\
\hline & \multicolumn{2}{|c|}{ Obesitas $(n=34)$} & \multicolumn{2}{|c|}{ Normal $(n=34)$} & \\
\hline & Ada & Tidak ada & Ada & Tidak ada & \\
\hline Tinggi & 20 & 10 & 10 & 13 & 0,04 \\
\hline Normal/rendah & 0 & 4 & 4 & 7 & \\
\hline
\end{tabular}


$(\mathrm{n}=10)$ maupun tanpa manifestasi penyakit atopik $(\mathrm{n}=13)$ dan secara statistik didapatkan perbedaan yang bermakna $(\mathrm{p}=0,04)$.

Kadar leptin yang bermakna dalam menimbulkan manifestasi penyakit atopik pada anak obesitas tertera pada Gambar 1.

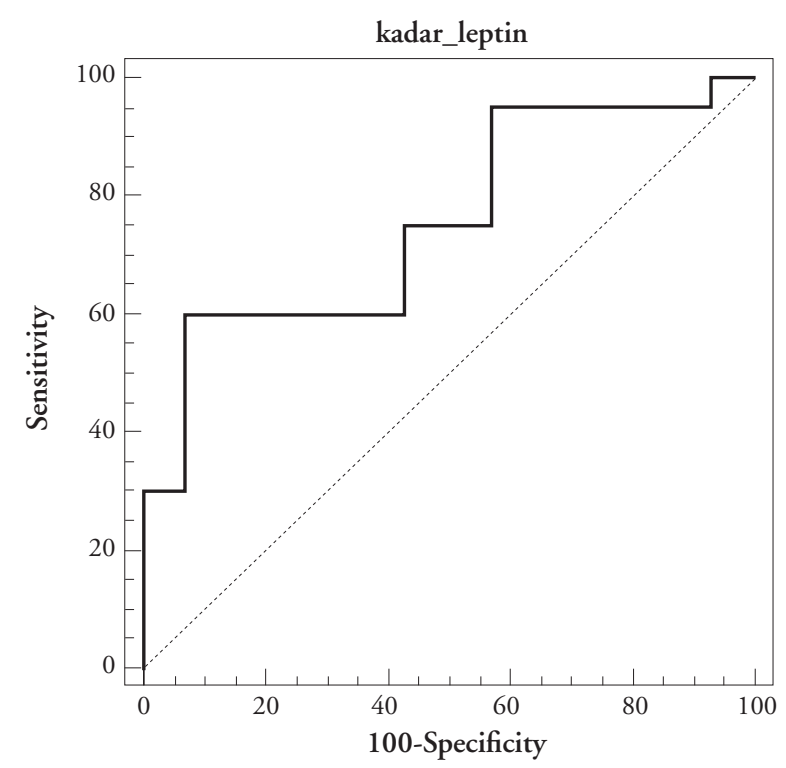

Gambar 1. Kadar leptin yang memengaruhi manifestasi penyakit atopik pada anak obesitas

Gambar 1 memperlihatkan nilai leptin yang berpengaruh pada timbulnya manifestasi penyakit atopik pada anak obesitas adalah bila kadar leptin serum $>22.503 \mathrm{pg} / \mathrm{mL}$.

\section{Pembahasan}

Pada penelitian ini didapatkan hasil kadar leptin serum tinggi lebih banyak didapatkan pada anak obesitas dengan manifestasi penyakit atopik dibandingkan dengan tanpa manifestasi penyakit atopik. Faktor yang memengaruhi atopi seperti genetik, yaitu riwayat adanya atopi dalam keluarga dan faktor lingkungan, seperti karpet, asap rokok, dan cara persalinan tidak didapatkan perbedaan antara anak yang memiliki manifestasi penyakit atopik dengan anak tanpa manifestasi penyakit atopik. Dengan demikian, hal tersebut tidak memengaruhi hubungan kadar leptin serum dengan manifestasi penyakit atopik.

Pada anak obesitas, mekanisme timbulnya manifestasi penyakit atopik berhubungan dengan adanya keadaan hiperleptinemia, yaitu produksi leptin yang berlebih dalam darah yang terjadi karena adanya gangguan pensinyalan leptin pada reseptor leptin. Keadaan resistensi leptin akan menyebabkan leptin tidak dapat bekerja pada reseptornya. Resistensi leptin akan menyebabkan supresi dari produksi sitokin Th1 dan sebaliknya akan terjadi peningkatan sekresi Th2 sehingga menyebabkan produksi sitokin Th1 menurun dan produksi sitokin Th2 seperti IL-4,IL-5, dan IL-3 akan meningkat. ${ }^{3,4}$ Sekresi IL-4 akan menyebabkan proses switching pada limfosit B sehingga limfosit B menghasilkan imunoglobulin $\mathrm{E}$ ( $\mathrm{IgE}$ ). Imunoglobulin spesifik adalah suatu penanda atopi. ${ }^{3-4,9-10}$

Leptin tidak hanya memodulasi aktivasi dan proliferasi limfosit $\mathrm{T}$, tetapi juga meningkatkan produksi sitokin. Efek leptin terhadap fungsi limfosit telah dievaluasi dengan immunostaining sitokin menggunakan analisis sitometri. Leptin meningkatkan produksi interleukin-2 dan interferon gamma sehingga menstimulasi limfosit $\mathrm{T}$. Leptin juga meningkatkan respon sel $\mathrm{T}$ sehingga cenderung mengarah ke fenotipe Th1. Sebaliknya, pada keadaan resistensi leptin, produksi sitokin Th1 menurun dan Th2 meningkat sehingga timbul atopi. ${ }^{3-4}$

Atopi adalah kecenderungan personal dan atau familial untuk menjadi tersensitasi dan menghasilkan $\mathrm{IgE}$ sebagai respon terhadap pajanan alergen. Istilah atopi tidak dapat digunakan sebelum bukti sensitisasi IgE yang ditandai dengan terdapatnya antibodi IgE spesifik dalam serum atau uji tusuk kulit yang positif. ${ }^{-11}$

Atopi sangat berkaitan dengan faktor sosioekonomi dan sanitasi lingkungan. Pada golongan sosioekonomi rendah dengan sanitasi lingkungan yang buruk, paparan alergen akan meningkatkan risiko terjadinya atopi. ${ }^{10,11} \mathrm{Di}$ Indonesia, sanitasi lingkungan belum baik sehingga terdapat banyak alergen yang memungkinkan seseorang mudah tersensitisasi sehingga kejadian atopi meningkat. Manifestasi penyakit atopik dapat berupa asma, rinitis, atau dermatitis atopi. ${ }^{10}$

Pembuktian penelitian ini untuk terjadi sensitisasi IgE dilakukan pemeriksaan uji tusuk kulit. Sebaliknya, untuk mengetahui apakah anak mempunyai manifestasi penyakit atopik digunakan kuesioner ISAAC. Kuesioner ISAAC dibuat oleh the international study of asthma and allergies in childhood (ISAAC) dan merupakan metodologi standar internasional untuk mengetahui 
prevalensi asma, rinitis, dan dermatitis atopi, serta telah digunakan luas dalam penelitian atopi. Pada kuesioner ISAAC terdapat juga pertanyaan mengenai faktor yang dapat memengaruhi timbulnya atopi, seperti adanya riwayat atopi dalam keluarga, paparan asap rokok, cara persalinan, dan penggunaan karpet. ${ }^{14}$

Penelitian yang menghubungkan kadar leptin serum dengan manifestasi penyakit atopik belum pernah dilakukan sebelumnya. Penelitian di Mesir tahun 2009, ${ }^{6}$ melaporkan hubungan kadar leptin dengan asma dan mendapatkan hasil bahwa kadar leptin lebih tinggi secara signifikan pada penderita asma. Kadar leptin asma atopi lebih tinggi dibandingkan non atopi. Kadar leptin yang tinggi juga berhubungan dengan semakin beratnya derajat asma. Dengan demikian, penelitian ini menyimpulkan bahwa kadar leptin merupakan faktor prediktif pada asma. Namun, subjek penelitian di Mesir tidak diperhitungkan status gizi anak dan tidak melihat hubungan leptin dengan manifestasi penyakit atopik yang lain.

Penelitian lainnya menghubungkan antara kadar leptin serum dengan kejadian asma atopi dan rinitis alergi pada anak dan menemukan hasil bahwa kadar leptin yang tinggi lebih berhubungan dengan kejadian asma dibandingkan rinitis alergi. Kadar leptin juga berhubungan dengan jenis kelamin perempuan dan overweight. ${ }^{7}$ Penelitian di Turki ${ }^{8}$ melaporkan hubungan kadar leptin dengan rinitis alergi; bahwa kadar leptin berhubungan dengan rinitis alergi terutama pada periode simptomatik sehingga diduga leptin berhubungan dengan proses inflamasi pada rhinitis alergi.

Penelitian yang telah dilakukan sebelumnya tidak melibatkan riwayat atopi dalam keluarga dan menggunakan serum IgE sebagai penanda atopi. Terdapat metode lain untuk mendiagnosis atopi, yaitu uji tusuk kulit. Keuntungan uji tusuk kulit adalah hasil yang didapat langsung terlihat, sensitivitas lebih baik, dan tidak terpengaruh kadar IgE total. Penelitian kami melibatkan riwayat atopi dalam keluarga dan menggunakan uji tusuk kulit.

Penelitian ini juga mendapatkan nilai cut off point kadar leptin serum yang dapat menimbulkan manifestasi penyakit atopik dengan hasil bahwa kadar leptin serum $>22.503 \mathrm{pg} / \mathrm{mL}$ yang dapat menimbulkan manifestasi penyakit atopik pada anak obesitas. Penelitian ini merupakan penelitian pertama yang meneliti kadar leptin yang dapat menimbulkan manifestasi penyakit atopik. Keterbatasan penelitian ini adalah manifestasi penyakit atopik hanya ditentukan berdasarkan hasil dari kuesioner ISAAC, bukan merupakan suatu diagnostik dari asma, rinitis alergi, maupun dermatitis atopik, jumlah sampel yang kecil tidak cukup untuk menggambarkan hubungan kadar leptin dengan dermatitis atopik, rinitis alergi, dan asma.

\section{Kesimpulan}

Kadar leptin serum tinggi lebih banyak didapatkan pada anak obes dengan manifestasi penyakit atopik dibandingkan dengan anak obesitas tanpa manifestasi penyakit atopik.

\section{Daftar pustaka}

1. Sharma S, Tailor A, Warrington R, Cheang M, Math $\mathrm{M}$. Is obesity associated with an increased risk for airway hyperresponsiveness and development of asthma? Allergy Asthma Clinical Immunol 2008;4:51-8.

2. Schneider M, Brill S. Obesity in children and adolescent. Pediatr Rev 2005;26:155-62.

3. Chan J, Matarese G, Shetty G, Raciti P. Differential regulation of metabolic, neuroendocrine, and immune function by leptin in humans. Proc Nat Acad Sci 2006;103:8481-6.

4. Matarese G, Moschos S, Mantzoros CS. Leptin in Immunology. J Immunol 2005;173:3137-42.

5. Litonjua A, Gold D. Ashtma and obesity: Common early-life influences in the inception of disease J Allergy Clin Immunol 2008;121:1075-84.

6. Nashwa M. Samra SZ, El-Sharkawi, Hoda M. Abd ElGhany, Zizi TM. Relationship between concentration of serum leptin and childhood asthma in Egypt. Res J of Med \& Medic Sci 2009;4:249-56.

7. Quek YW, Sun HL, Ng YY, Lee HS, Yang SF, Ku MS, dkk. Association of serum leptin with atopic asthma and allergic rhinitis in children. Am J Rhinol Allergy 2010;24:354-8.

8. Murat U, Gulcin E, Muslu N, Pata Y, Akbas Y. Serum leptin levels in patients with allergic rhinitis. OTO-HNS 2006;134:331-3.

9. Kay A. Allergy and allergic disease. N Engl J Med 2001;334:30-7.

10. Stone K. Atopic diseases of childhood. Curr Opin Pediatr 2003;15:495-511.

11. Weinberger M. Clinical patterns and natural history of asthma. J Pediatr 2003;142:15-20.

12. Sicherer S, Sampson H. Food Allergy. J Allergy Clin 
Dita Lasendra dkk: Hubungan antara kadar leptin serum dan manifestasi penyakit atopik pada anak obes

Immunol 2010;124:116-25.

13. Johansson S. World allergy organization guidelines for prevention of allergy and allergic asthma. Int Arch Allergy Immunol 2004;135:83-92.
14. Asher M, Keil U, Anderson H, Beasley R, Crane J, Martinez F, dkk. International study of asthma and allergies in childhood (ISAAC):rationale and methods. Eur Respir J 1995;8:483-91. 